\title{
The Transatlantic Trade and Investment Partnership - The Revival of Bilateralism? HORVÁTHY Balázs
}

Széchenyi István University

Faculty of Law and Political Sciences

Department for Public and Private International Law

Györ, Hungary

HAS CSS Institute for Legal Studies

Budapest, Hungary

Email: horvb@ga.sze.hu

\begin{abstract}
The trade negotiations between the EU and the US on the Transatlantic Trade and Investment Partnership (TTIP) are obviously showing that the regulation of international economic and trade relations is tending to go off the track of multilateralism and switch to the bilateral regulation of international trade between the two major economic blocs of the world. Moreover, the T-TIP might overstep the borders of the multilateral framework of the trade liberalization, doing far more than merely to eliminate the already low average tariffs and targets the non-tariff barriers as well that are typical trade obstacles for the relations between the well-developed industrial nations. The main aim of the present paper is to analyze the characteristics of this bilateral segment of world trade, provide a general examination of the trade relations between the EU and US, and analyze the EU negotiation mandate.

Keywords: Transatlantic Trade and Investment Partnership, Bilateral trade agreements, Trade and Environment, Foreign direct investments
\end{abstract}

JEL classification: K33 International Law; F21 International Investment, Q56 Environment and Trade

\section{INTRODUCTION}

The trade negotiations between the EU and the US on the Transatlantic Trade and Investment Partnership (T-TIP) has been launched last year, aiming the most ambitious - 'comprehensive' (Barroso $)^{l}$ and 'high-standard' (Obama) ${ }^{2}$ - trade agreement ever attempted, due to both its scale and its significance for the transatlantic relationship between the European Union and the United States. Moreover, this time the chances of success of an agreement seem more feasible than ever. From economic point of view, the growth is weak equally in the EU and the US, however, the monetary and fiscal policy instruments are largely exhausted. ${ }^{3}$ The trade growth has been slow-moving because of the effects of the financial crisis of 2008-2009 and competing subsidy and regulatory policies that impede commercial activity. ${ }^{4}$ Structural reforms are demanded in both regions, from which the prospect of economic growth is expected. Moreover, both EU and US have widely lost market shares in the last two decades. Therefore, the liberalization of bilateral trade relations could increase their ability to compete with the emerging economies.

On the other hand, from the perspective of the international economic law, the negotiations on the TTIP are showing, that the regulation of international economic and trade relations is tending to go off

\footnotetext{
1 "A future deal will give a strong boost to our economies on both sides of the Atlantic. It will be a comprehensive agreement going beyond tariffs, by integrating markets and removing barriers. It is estimated that, when this agreement is up and running, the European economy will get a stimulus of half a per cent of our GDP - which translates into tens of billions of euros every year and tens of thousands of new jobs." Speech of José Manuel Durão Barroso, former President of the European Commission. See: BARRoso, JosÉ MANUEL DURÃO: Statement on the Transatlantic Trade and Investment Partnership. Joint press conference, Brussels (13 February 2013), available at: http://europa.eu/rapid/press-release_SPEECH-13-121_en.htm [cit. 2014-12-19].

2 "Promoting growth, creating jobs, strengthening the middle class-these are the principles that animate President Obama's economic policies, including this Administration's trade policy. As President Obama said [...], T-TIP can be a success if »we can achieve the kind of high-standard, comprehensive agreement that the global trading system is looking to us to develop. " Michael Froman, the U. S. Trade Representative cited president Obama in his speech, see: FrOMAN, MichAEL: Remarks at the Transatlantic Trade and Investment Partnership First Round Opening Plenary (July 8, 2013), in Law and Business Review of the Americas, 2013, Vol. 19. (2013) 135-136.

${ }^{3}$ See Felbermayr, Gabriel J. - LARCH, MARIO: The Transatlantic Trade and Investment Partnership (TTIP): Potentials, Problems and Perspectives, in CESifo Forum, Vol. 14 (2013) No. 2. 49-60.

4 Schott, Jeffrey J. - Cimino, CAthleEN: Keys to negotiating the transatlantic trade and investment partnership, in Intereconomics, Vol. 48. (2013) No. 4. 263-264.
} 
the track of multilateralism and switch obviously to the bilateral regulation of international trade between the two major economic blocs of the world. Moreover, the T-TIP could overstep the borders of the multilateral framework of the trade liberalization, doing far more than merely to eliminate the already low average tariffs and targets the non-tariff barriers as well, which are typical trade obstacles for the relations between the well-developed industrial nations. ${ }^{5}$

The main aim of the present paper is to analyze the characteristics of this bilateral segment of world trade from the perspective of the international economic law. The paper starts with a general examination of the bilateral trade relations between the EU and US, then, it goes over the EU negotiation mandate, highlighting two specific and disputed fields, the trade and environment, and the investment provisions.

\section{THE RISE OF BILATERALISM AND THE EU-US TRADE NEGOTIATIONS}

"We are living in a trading environment of bilateralism" - Abbott has admitted already in 2007, and made attempts to examine the possible consequences of the rising bilateral trends in the EU trade policy. ${ }^{6}$ The current EU-US negotiations can be regarded also a part of this tendency, which is now suggesting that, the significant trading countries or trade blocs, like the European Union are seeking more frequently the opportunities in the bilateral trade negotiations, instead of bringing the even extending trade agenda to multilateral level. In more concrete terms, it means that the postponement of the Doha Round has somewhat weakened the desire for multilateral trade agreements, ${ }^{7}$ and bilateral agreements, or regional integrations seem to be back in favor. ${ }^{8}$ The advantages of the revival of bilateralism are quite palpable: while multilateral negotiations are more comprehensive and beneficial at global level, bilateral agreements are faster, and the countries involved can focus purely on their requirements without having to build common negotiating objectives among blocs of countries. ${ }^{9}$ Moreover, achievements from bilateral negotiations can be accomplished gradually, and bilateral negotiations also enable countries to give more reflections on the regional and socio-political conditions of the negotiating parties, which can pave the way to reach compromises on 'tailor-made' agreements. This feature is hardly feasible in multilateral negotiations.

In terms of the trade statistics, the EU and the US have already the largest bilateral trade relationship in the world. Each is the other's largest export market, and the investment relations between the two trade blocs are also significant. The US-EU bilateral trade in goods and services totals approximately 1000 billion annually, and the US and the EU are also heavily investing in each other's market (almost $3000-4000$ billion $\$$ a year). ${ }^{10}$ In other terms, the US invests considerably more in the EU than in all of Asia - three times more according to the European Commission - while the EU invests considerably more in the US than in China and India combined - eight times more. ${ }^{11}$

The T-TIP is not the first attempt to conclude an EU-US bilateral trade agreement. Between 1994 and 1996, a Transatlantic Free Trade Area (TAFTA) was under discussion, but formal negotiations were never started. ${ }^{12}$ This was because the priority at that time was to ensure the stability of the newly formed World Trade Organization (WTO. The current negotiations are rooted in a summit meeting

\footnotetext{
${ }^{5}$ According to the EU Commission's document, it is actually an average of $4 \%$, see: Recommendation for a Council Decision authorizing the opening of negotiations on a comprehensive trade and investment agreement, called the Transatlantic Trade and Investment Partnership, between the European Union and the United States of America. $\operatorname{COM}(12.3 .2013) 136$ final. There are some tariffs peaks for sensitive products on both sides of the Atlantic, e.g. tobacco, textiles and clothing, sugar, footwear, dairy products and some vegetables.

${ }^{6}$ AвbotT, Frederick M.: A new dominant trade species emerges: Is bilateralism a threat? in Journal of International Economic Law, Vol. 10. (2007) No. 3. 571-583.

7 BARUA, AKRUR - BANDYOPADHYAY, SUNANDAN: Revival in international trade and the resurgence of bilateralism, in Global Economic Outlook, (2014) No. 2. 60. Available at: http://dupress.com/articles/globaleconomic-outlook-q2-2014-revival-in-international-trade-and-the-resurgence-of-bilateralism/ [cit. 2014-12-19].

${ }^{8}$ Cf. PARDAVI LÁSZLó: A globális gazdaság vámjogának alapkérdései (különös tekintettel a preferenciális szerzödésekre) [Main questions of the global economy's customs law (with specific regard to the preferential agreements)], Dissertation (manuscript), 2014, Széchenyi István University, Győr. 55.

${ }^{9}$ BARUA - BANDYOPADHYAY: op. cit. 60-61.

${ }^{10}$ SCHOTT - CIMINO: op. cit. 263.

${ }^{11}$ See trade policy website of the European Commission, available at http://ec.europa.eu/trade/policy/countriesand-regions/countries/united-states/ [cit. 2014-12-19].

${ }^{12}$ WRÓBEL, ANNA: Multilateralism or bilateralism: The EU trade policy in an age of the WTO crisis, Ekonomika, Vol. 92. (2013) No. 3. 20.
} 
held on 28 November 2011, when Commission President José Manuel Barroso, EU President Herman Van Rompuy and US President Barack Obama established the High Level Working Group on Jobs and Growth (HLWG). The task of the Group was to identify policy measures, which are capable to increase trade and investment between the two major economic areas, the United States and the European Union. ${ }^{13}$ The HLWG has issued an interim report in 2012, which referred to the conclusion of a bilateral trade agreement as the best policy option. The final report has been adopted on 13 February 2013. ${ }^{14}$ The Free Trade Agreement was cordially announced by US President Obama and EU Commission President Barroso. Following the final report of the HLWG, it was recommended to open negotiations for a Free Trade Agreement of the EU with the United States. According to the report, the subject of the negotiations shall be the liberalization of agricultural products, industrial goods, services, of public procurement and investments as well as a regulation of intellectual property rights.

\section{THE EU'S MANDATE AND THE 'RED-HOT' ISSUES OF THE NEGOTIATIONS}

\subsection{Obscurity over the EU negotiation mandate and the main objectives of the T-TIP}

The European Commission has elaborated the framework of mandate for the negotiation in March 2013, however only its short summary has been published. ${ }^{15}$ According to the frequently criticized EU practice, in the field of external trade, the whole text of the negotiating mandate is never published, as it is always submitted to the Council and the Parliament as restricted - i.e. confidential - document. As a result, officially we shouldn't know further information than the above mentioned summary and some other clarifications made public by the European Commission. Not surprisingly however, the negotiation mandate classified as 'restricted document' has been leaked quickly, and it was accessible on the internet even today. In late November 2014, the Commission has changed its policy regarding the 'secrecy' of international trade negotiation, and made commitments to conduct a more transparent trade policy and provide more space for public participation. ${ }^{16}$

However, some 'hints' can help to cover up the objectives of the negotiations. As the name of preparatory body of the negotiations suggested ('High Level Working Group on Jobs and Growth'), the overriding policy objectives of the T-TIP is to create more jobs and boosting economic growth. The expected impacts were analyzed in a commissioned study published in $2013,{ }^{17}$ which have estimated the overall economic impacts, ${ }^{18}$ as well as the sectorial impacts ${ }^{19}$ of an eventual conclusion of an ambitious T-TIP between EU and US. However, from legal and regulatory point of view the most important question is that how these economic gains arise? According to the 2013 study of CEPR, the key part of the liberalization within the prospective T-TIP will be the reduction of non-

\footnotetext{
${ }^{13}$ The bilateral trade relationship is extremely important for both partners. The EU is first trading partner of the US (17.6\% in trade in goods), and the US is the EU's second largest trading partner with $13.9 \%$ in trade in goods. Together the EU and the US account for approx. 50\% of global GDP, 1/3 of total world trade. Bilateral trade volume of goods and services amounted to 702.6bn euro (2011), bilateral investment stock was 2.394 trillion euro (2011). See Commission Staff Working Document - Executive Summary of the Impact Assessment on the Future of the EU-US Trade Relations, SWD(12.3.2013) 69 final, p. 2.

14 Final Report High Level Working Group on Jobs and Growth (February 11, 2013), available at: http://trade.ec.europa.eu/doclib/docs/2013/february/tradoc_150519.pdf [cit. 2014-12-19].

${ }_{15}$ Member States endorse EU-US trade and investment negotiations, DG Trade News Archive (14 June 2013), available at: http://trade.ec.europa.eu/doclib/press/index.cfm?id=918 [cit. 2014-12-19].

${ }^{16}$ To be more precise, the Commission was pressurized by the Ombudsman and the CJEU in order to involve the public into the decisions on international trade issues. See especially, C-350/12 P. Council versus in 't Veld, ECLI:EU:C:2014:2039.0

${ }^{17}$ Centre for Economic Policy Research (CEPR) for European Commission - Reducing Transatlantic Barriers to Trade and Investment: An Economic Assessment (March 2013; hereinafter: CEPR assessment paper), available at http://trade.ec.europa.eu/doclib/docs/2013/march/tradoc_150737.pdf [cit. 2014-12-19]. The study suggested, that an ambitious agreement could bring significant economic gains as a whole for the EU ( $€ 119$ billion a year) and US ( $€ 5$ billion a year). This translates to an extra $€ 545$ in disposable income each year for a family of 4 in the EU, on average, and $€ 655$ per family in the US.

${ }^{18}$ It is also interesting the benefits for the EU and US would not be at the expense of the rest of the world. On the contrary, liberalizing trade between the EU and the US would have a positive impact on worldwide trade and incomes, increasing global income by almost $€ 100$ billion.

${ }^{19}$ Income gains are a result of increased trade. EU exports to the US would go up by $28 \%$, equivalent to an additional $€ 187$ billion worth of exports of EU goods and services. Overall, total exports would increase $6 \%$ in the EU and $8 \%$ in the US.
} 
tariff barriers, it will be a key part of transatlantic liberalization. The study has concluded that the majority - as much as $80 \%$ - of the total potential gains might come from cutting costs imposed by trade bureaucracy and regulations, as well as from liberalizing trade in services and public procurement. $^{20}$

In addition to that, according to the short texts, and other summarizing documents brought out by the Commission, at least the directions of the negotiations can be already seen. In terms of that, the objectives of the negotiations cover two big areas and other miscellaneous issues.

Firstly, the EU is trying to put the questions of the market access on the agenda. The market access encompasses the following main topics:

- removing tariffs on transatlantic trade in industrial and agricultural products;

- reconciling the EU and the US approaches to rules of origin, which are used to determine the origin of a product for the purpose of trade rules;

- discussing the question of the Trade Defence Measures, namely, the EU wants to establish a regular dialogue with the US on anti-dumping and anti-subsidy measures;

- opening up more access for transatlantic trade in services, at both federal and sub-federal level, and to ensure that European professional qualifications can be recognized in the US;

- securing investment liberalization at both federal and sub-federal level and potentially, to establish investment protection provisions;

- providing access to government procurement markets at all levels of US government.

The second big issue is the elimination of the regulatory trade barriers. This term refers to a variety of trade obstacles, which can take different forms. In general, two main categories are covered by the term 'non-tariff-barriers.' Firstly, it includes the whole range of quantitative restrictions that directly restrict market access (e.g. import quotas), and secondly, it covers regulations, which add to the cost of exporting into that market, e.g. domestic regulations requiring expensive reconfiguration of products, such as changing voltage or adapting the technical parameters (environmental standards of cars, standards and product requirements of foods, administrative measures, e.g. price controls etc.). Therefore the terms refers typically to the so-called 'behind-the-border' barriers to trade. ${ }^{21}$ From the perspective of their effects, this category might cover, e.g. the need to have to allow products separately for both markets, often on the basis of different procedures and conditions for admission; different environmental, health or consumer protection policy standards: different industrial standards, packaging requirements and information or labelling obligations; regulation of access to public procurement procedures or economic development programs, such as the state export credit insurance, etc. 22

These differences in domestic regulations, technically, can be addressed by three major approaches. ${ }^{23}$ The first method is the unification, which provides a tool for establishing the same requirements in all contracting countries. However, the unification has its own limitations; namely, if strong industrial actors are competing in the market at stake, setting common standards is much more than difficult. However, it is not impossible, even today unified standards are working in several areas, like telecommunication, IT technologies, automotive industry, or international aviation and maritime transport. Secondly, the harmonization implies the alignment of regulations to a single best practice. Usually a voluntary agreement, harmonization can be based on a reference to international standards from a standard-setting body, or simply involve coordination among nations. Countries basically agree to converge on a single standard or regulation. This is usually the most difficult way to achieve

\footnotetext{
${ }^{20}$ See Independent study outlines benefits of EU-US trade agreement, European Commission, MEMO/13/211 (12 March 2013), available at: http://europa.eu/rapid/press-release_MEMO-13-211_en.htm [cit. 2014-12-19].

${ }^{21}$ See SAdiKov, AzIM: Border and Behind-the-Border Trade Barriers and Country Exports, IMF Working Paper (WP/07/292), December 2007. Available at: https://www.imf.org/external/pubs/ft/wp/2007/wp07292.pdf [cit. 2014-12-19].

${ }^{22}$ Expressive examples are examined by Lester and Barbee, illustrating how fruit and vegetable product can sizes, or car headlights standards can operate as regulatory trade barriers, see: LESTER, SIMON - BARBEE. INU: The Challenge of Cooperation: Regulatory Trade Barriers in the Transatlantic Trade and Investment Partnership, Journal of International Economic Law, Vol. 16. (2013) No. 4. 848.

${ }^{23}$ LESTER, SIMON: Tackling Regulatory Trade Barriers in the Transatlantic Trade and Investment Partnership, in Cardoso, Daniel et. a. (eds.): Transatlantic Colossus - Global Contributions to Broaden the Debate on the EUUS Free Trade Agreement, 2013, Berlin Forum on Global Politics, Berlin, 84.
} 
regulatory cooperation, in part because countries are reluctant to adjust their standards, and also because the harmonization of standards requires complete consensus. Thirdly, the principle of mutual recognition can also help to eliminate the regulatory trade barriers; it is especially useful in eliminating duplicative testing and certification processes. ${ }^{24}$

All of these approaches would facilitate trade by reducing the regulatory hurdles faced by prospective exporters both sides, in that they would save them the trouble of complying and/or demonstrating that they have complied with, a different regulatory regime. The question arises, however, how the EU and US can find compromise on these issues. Probably, the solution should simply be to remove regulatory divergences that are accidental or serve no purpose, however, it is inevitable that some inefficiency and higher costs must be accepted by both negotiating parties. ${ }^{25}$

In addition to the market access, and the regulatory trade barriers, the objectives of the EU encompass other particular and colorful issues, such as the intellectual property rights ${ }^{26}$, customs and trade facilitation, trade in energy and raw materials, trade-related aspects of small and medium-sized enterprises, state-owned enterprises, or trade and environment, and the inclusion of investment arbitration clauses.

It would not be feasible to extend the analysis to the whole range of the covered topics, however, we refer to specific examples, which shed light on the particularity of the European perspective and can give illustration of issues - 'red-jot issues' -, over which the negotiating parties have considerably divergent visions. The first example focus on the trade and environment issues, the second will examine the debate on the investment arbitration.

\subsection{Example 1: Trade and environment on the agenda of the transatlantic negotiations}

The role and stance of the European Union to the 'Trade and Environment' debate, ${ }^{27}$ comparing with the US position, represents a very strong commitment to the real inclusion of environmental concerns into the legal framework of the world trade. From the perspective of the ongoing negotiation on a transatlantic free trade and investment partnership agreement, it means that successful compromise can be reached only if the striking divergence between the positions of the parties can be reconciled. However it is hard to pave the way to a mutually acceptable agreement not only because of the big differences in the positions of the parties, but also because of their specific interest. At the current stage of the negotiations it is hardly possible to foresee, which compromise could be found regarding the disputed issues, in which the EU has expressed crucial interest in the last two decades (from the past e.g. GMOs, hormone treated beef and pork, chlorine-sterilized chicken, or quite recent disagreements on the so called 'fracking' shale gas reserves).

However, is the reconciliation of these positions really required? On the one hand, technically, it is not, in other terms an agreement could be concluded without real inclusion of 'bridges' between the

\footnotetext{
${ }^{24}$ Both the EU and the US have already concluded Mutual Recognition Agreements (MRAs), and even the EU and the US has common agreement on specific issues. The MRAs have the objective of promoting trade in goods between the contracting parties by facilitating market access. They are, in general, bilateral agreements, and aim to benefit industry by providing easier access to conformity assessment. The EU has currently MRA with USA, and Australia, Canada, Japan, New Zealand, Switzerland.

${ }^{25}$ See Lester's example: if a car producer wants to sell vehicles in the United Kingdom, it must account for the UK's use of left-hand drive traffic. LESTER - BARBEE: op. cit. 856.

${ }^{26}$ The main objective here is to reconcile different US and EU approaches to specific issues, such as protection for Geographical Indications, which is vital in several EU made products, e.g. Tokaji vine, or parma ham.

${ }^{27}$ See for 'Trade and Environment' debate, ARAYA, MONICA - FIGUERES, JoSE MARIA - SALAZAR-XIRINACHS, JOSE M.: Trade and Environment in the World Trade Organization: The Need for a Constructive Dialogue, in SAMPSON, GARY (ed.): The Role of the WTO in Global Governance, 2001, United Nations University Press, New York, 156.; SANTARIUS, TILMAN ET AL.: Balancing Trade and Environment: An Ecological Reform of the WTO as a Challenge in Sustainable Global Governance, 2004, Wuppertal Institute for Climate, Environment and Energy, Wuppertal, 18.; KESERÜ BARNA ARNOLD: A fenntartható fejlődés a GATT-WTO normarendszer tükrében [The sustainable development in the light of the GATT-WTO law], Diskurzus, 2013. 34-41.; KESERÜ BARNA ARNOLD: Review on the Role of Green Technologies in Hungarian Policies Concerning Sustainability, in KÁLMÁN JÁNOS (ed.): Legal Studies on the Contemporary Hungarian Legal System, 2014, Universitas-Györ Nonprofit Kft., Györ, 190-223.; VíG ZoLTÁN: Szabadkereskedelem és környezetvédelem: a WTO Vitarendezési Testületének gyakorlata [Free trade and environment: the case law of the WTO Dispute Settlement Body], in CSEHi Zoltán - RAfFai Katalin (eds.): Állam és magánjog [State and private law], 2014, Pázmány Press, Budapest, 427-438.
} 
trade and environmental concerns. On the other hand, the chance of the ratification of such a treaty would be precious little. The specificity of the EU's position to the 'Trade and Environment' issues has its roots not only in the EU law which was examined above, but also in a kind of European sensitivity to environmental concerns. Therefore an agreement without the real inclusions would be politically unacceptable in Europe. Over this, the question can be raised finally, what kind of compromise would mean a real solution, which can bring the concerns of trade as well as of environment together. Essentially, four basic concerns could be highlighted, which are pivotal elements of an 'environmentally conscious' trade agreement.

An 'environmentally conscious' trade agreement sets down the most important, environmentally relevant principles and objectives and makes clear the relationship between these principles and the principles of the free trade. It is important to ensure that these principles and objectives have legal effects as well (e.g. as tools of the interpretation in the dispute settlements etc.), and that the principles of the free trade should not overrule the environmental principles and objectives. The principle structure of the EU funding treaties furnishes a good instance of that solution, when introducing a clear hierarchy between the environmental concerns, as the general principle of the EU's external activities, and the free trade and liberalization, as principles of the Common Commercial Policy. The negation mandate of the European Union is a good base towards this compromise, but at this time, the details in this regard are not clear. According to the public summary of the mandate, this part of the agreement (e.g. its preamble) should express the commitment to sustainable development and the contribution of international trade to sustainable development "[...] in its economic, social and environmental dimensions, including economic development, full and productive employment and decent work for all as well as the protection and preservation of the environment and natural resources [...]." 28 Questionable is, however, the notion of 'sustainable development'. If we interpret this reference in context with the EU law, the proposition of the EU is that the agreement should recognize the sustainable development as an overarching objective, as well as the aim of the parties at promoting high levels of protection for the environment. In this regard, the mandate emphasizes a specific objective as well. In terms of that the Agreement should also recognize that the Parties will not encourage trade or foreign direct investment by lowering domestic environmental standards. In other words, the agreement should prevent the 'race to the bottom' effect, which could lead to sinking the level of protection in the contracting parties.

Second, the agreement should cover also substantive provisions, which enables the parties to introduce measures with the intention to realize environmental objectives. However, the real question is whether also the guaranties should be established, which can prevent the parties from introducing illicit discriminatory measures in this way. In this regard the mandate is not clear enough, it refers only general statements which are in line with the proposed principles and objectives, but the material content of this chapter is questionable. The mandate stresses only that the separate chapter of 'Trade and sustainable development' will include commitments by both parties in terms of the trade and sustainable development. Consideration will be given to measures to facilitate and promote trade in environmentally friendly and resource-efficient goods, services and technologies, including through green public procurement and to support informed purchasing choices by consumers. Besides the Agreement will also include provisions to promote adherence to and effective implementation of internationally agreed standards and agreements in the labor and environmental domain as a necessary condition for sustainable development ${ }^{29}$ end the importance of implementation and enforcement of domestic legislation on labor and environment should be stressed as well. It should also include provisions in support of internationally recognized standards of corporate social responsibility, as well as of the conservation, sustainable management and promotion of trade in legally obtained and sustainable natural resources, such as timber, wildlife or fisheries' resources. The future Agreement will foresee the monitoring of the implementation of these provisions through a mechanism including civil society participation, as well as one to address any disputes.

\footnotetext{
${ }^{28}$ See Recommendation for a Council Decision authorizing the opening of negotiations on a comprehensive trade and investment agreement, called the Transatlantic Trade and Investment Partnership, between the European Union and the United States of America. COM (12.3.2013) 136, paragraph 6.

${ }^{29}$ Recommendation for a Council Decision... COM (12.3.2013) 136, paragraph 25.
} 
It should be also noted that the mandate refers, among the market access rules, to the general exceptions under the WTO law, noting that the agreement should have a general exception clause based on Articles XX and XXI GATT and Articles XIV and XIVbis GATS. In context with the nontariff barriers, the agreement should reflect also on the specificity of Sanitary and phytosanitary measures (SPS). According to the mandate, on SPS measures, the negotiations shall follow the former negotiating directives of the EU. ${ }^{30}$ In terms of that, the parties shall establish provisions that build upon the WTO SPS Agreement and on the provisions of the existing veterinary agreement, introduce disciplines as regards plant health and set up a bilateral forum for improved dialogue and cooperation on SPS issues. Moreover the chapter on the SPS measures should be based on "[...] the key principles of the WTO SPS Agreement, including the requirement that each side's SPS measures be based on science and on international standards or scientific risk assessments, applied only to the extent necessary to protect human, animal, or plant life or health, and developed in a transparent manner, without undue delay [...]." ${ }^{31}$ In addition to that the proposed agreement should also touches upon the technical regulations, which is also an important regulatory area from environmental perspective. In line with the WTO Agreement on Technical Barriers to Trade (TBT), the EU's mandate foresees also provision. The objectives of these provisions would be to generate greater openness, transparency and convergence in regulatory approaches and requirements and related standards-development processes, as well as, inter alia, to reduce burdensome testing and certification requirements, promote confidence in our respective conformity assessment bodies, and enhance cooperation on conformity assessment and standardization issues globally.

Third, essential element of such an agreement is also a dispute resolution system, which is able to effectively reconcile the disagreements of the contracting parties. In this regard the main point is that the proposed the dispute resolution procedure should be applied to the 'Trade and Sustainable Development' chapter. In other terms the agreement has to express clearly that the same implementation requirements are to be applied to this chapter as for all other content of the agreement. The EU mandate touches upon the question of the dispute resolution but it is silent on its possible extent, therefore it is still unknown, how these requirements will be applied to the trade and environmental matters.

Finally, the fourth requirement is that a trade agreement which takes into consideration the environmental interest should make clear its relationship to the multilateral environmental agreements. One option could be that the most important relevant agreements previously concluded by the $\mathrm{EU}^{32}$ are to be listed explicitly in the text agreement. This concern is totally in compliance with the EU commitments to these issues, as it was mentioned before, the EU has intended to make provision regarding the multilateral environmental agreements already in the course of the Uruguay round. However, the current and publicly accessible information on the EU mandate is silent on this issue.

\subsection{Example 2: Investor-State Dispute Resolution in the T-TIP}

As the title of the T-TIP suggests, it will contain provisions regarding the investment activities as well. The typical feature of the investment treaties is the set of rules providing mutual protection for investors, including specialized mechanism of dispute resolution (Investor-State Dispute Resolution ISDS). The ISDS can be regarded as a general 'guarantee' of the agreement that entitles the investors to initiate procedures directly against the host state, if it is deemed to breach the obligations arising from the agreement. The main reason of the ISDS clauses in the investment treaties is to provide an investor-friendly environment and encourage the foreign investments in the participating countries. However, the ISDS is recently in center of debates, specifically in the European Union. Problematic is not only the ongoing negotiation on T-TIP, but we can currently observe also a competence struggle between the European Union and its Member States. It is because the Treaty of Lisbon established the framework of the exclusive competence in the field of the foreign direct investments, however, the

\footnotetext{
${ }^{30}$ Adopted by the Council on 20 February 1995, see Council Doc. 4976/95.

${ }^{31}$ See Recommendation for a Council Decision... COM (12.3.2013) 136, paragraph 18.

32 The most significant agreements are as follows: Montreal Protocol on Ozone Depleting Substances, Basel Convention on the Control of Transboundary Movements of Hazardous Wastes and their Disposal, Stockholm Convention on Persistent Organic Pollutants, Convention on International Trade in Endangered Species of Wild Fauna and Flora, Convention on Biological Diversity, Rotterdam Convention on Prior Informed Consent Procedure for Certain Hazardous Chemicals and Pesticide.
} 
more than 1000 bilateral treaties previously concluded by the Member States could not yet replaced by new Treaties negotiated by the European Union, therefore the Member States are allowed to maintain their old investment treaties and relationships for a transitory period..$^{33}$ The European Commission is wholly concerned over the application of the new Union competence and it clearly wants to uphold this issue on the agenda of the T-TIP negotiations in spite of the weighty public opposition. Consequently, the T-TIP seems to be a 'pilot project' of the Commission, which might indicate the particularity of the competence division between the Union and the Members States and have a longterm effect on the EU investment policy, hoping, that the T-TIP would serve as a model agreement for the future negotiations, thus the T-TIP would have precedent value in this respect.

However, neither all Member States, nor the academia are convinced about the necessity of the investment provisions. Among the EU Member States, Germany has expressed the harshest criticisms on the necessity of the investment chapter and of ISDS provisions within the T-TIP, highlighting a several concerns about the inclusion of investment protection provisions. It was argued, that these provisions might lead to litigious activity against EU member states by US investors, which observation was based on the empiric experiences, which are showing, that that US had launched by far the largest number of ISDS claims and were supported by "equally litigious" US law firms, who "dominate the global arbitration business. ${ }^{34}$

In addition, the academia has publicly criticized the proposed ISDS clause in T-TIP as well. The worldwide known international law professor, Martti Koskenniemi has highlighted a number of concerns that are to be considered, if the EU would decide to put the question on the negotiation agenda. ${ }^{35}$ Firstly, he remarked, that the ISDS clause is not adequate in the USA-EU relationship. It is because corporations investing in unstable, typically non-democratic economies demand investment protection regulations, however the EU and the EU member states are based on the principle of democracy and rule of law. Secondly, he criticized the method of investment arbitration as well, underlining the weaknesses of the current models of dispute settlements, specifically the World Bank's International Centre for Settlement of Investment Disputes (ICSID). Koskenniemi highlighted, that over a half of the disputes brought to the ICSID have been resolved by 15 lawyers, who has the possibility to represent also parties in the procedures, and since the body has no permanent composition, its rulings lack cohesion and coherency. Koskenniemi referred also to an assumption, which governs this judicial body, namely that all investors act in good faith (bona fide), therefore investors acting in mala fide are not accounted for. If the T-TIP will establish a similar body similar, law firms will wrangle on every possible clause of international legislation. Thirdly, he noted, that such disputes generally arise in the fields, which are strictly regulated by the state. In Finland, clauses of social, employment or environmental laws would be particularly susceptible to disputes. A foreign mining company could, for example, initiate legal action against Finland for restricting its operations. He refers to the case of Tobacco company Philip Morris, in turn, initiated legal action against Australia after it decreed that cancerous lungs be imprinted on cigarette packs.

Besides it is notable, that also a formal 'academic opposition' has been launched in July $2014 .{ }^{36}$ A group of 120 academic experts ${ }^{37}$ in trade and investment law, EU law, international law and human

33 See 1219/2012/EU European Parliament and Council Regulation (12 ${ }^{\text {th }}$ December 2012) establishing transitional arrangements for bilateral investment agreements between Member States and third countries. It is worth noting, that eight member states have own bilateral investment treaty also with the United States, therefore the T-TIP would replace all these existing individual Bilateral Investment Treaties (BITs) between the US and the Member States concerned.

${ }^{34}$ According to the United Nations Conference on Trade and Development, of the 247 concluded cases known by the end of 2013, around $43 \%$ were decided in the state's favor and $31 \%$ in favor of the investor. The rest (26\%) were settled. TTIP and the Arbitration Clause, in Euractiv Special Report (8-12 December 2014$), 1$. Available at: http://www.euractiv.com/files/euractiv_special_report_- ttip_and the arbitration_clause.pdf [cit. 2014-12-19].

${ }^{35}$ See Professor: Finland's legislative power may be in jeopardy, in Helsinki Times (15 Dec 2013), available at: http://www.helsinkitimes.fi/finland/finland-news/domestic/8717-professor-finland-s-legislative-power-may-bein-jeopardy.html [cit. 2014-12-19].

36 Statement of Concern about Planned Provisions on Investment Protection and Investor-State Dispute Settlement (ISDS) in the Transatlantic Trade and Investment Partnership (TTIP), available at: https://www.kent.ac.uk/law/isds treaty_consultation.html [cit. 2014-12-19]. The submission was written by 
rights, constitutional law, private law, political economy and other fields has spoken out against planned provisions on ISDS in T-TIP. The action coordinated by the University of Kent, has been a contribution to the public consultation announced by the European Commission. ${ }^{38}$ The expert group criticized the Commission for failing to make a plausible case for the need for investment protection provisions in T-TIP in the first place, and for excluding views on their desirability from the consultation exercise. Based on the consultation document published by the Commission, the expert group found that the proposed text, amongst other shortcomings, specifically

- Allows for unwarranted discretion for arbitration tribunals in the application of various 'necessity' tests;

- Fails to exclude acquisitions of sovereign debt instruments from the scope of the Treaty;

- Allows anyone with a substantial business activity in the home state who holds any 'interest' in an enterprise in the host state to bring a claim;

- Fails to spell out legal duties of investors in host states;

- Fails to control the expansion of investment arbitration to purely contractual claims;

- Fails to protect the 'right to regulate' as a general right and as a component of the Fair and Equitable Treatment (FET) and Expropriation standards of protection of investors;

- Fails to further the stated principle of favoring domestic court proceedings, and

- Fails to regulate conflicts of interest in the arbitration process.

Although the scholars emphasized that the proposed text has been rather better than many investment treaties, they added that "the nature of the problems associated with investor-state arbitration is not quite as straightforward as the Commission presents it. In a strange cat-and-mouse game, the Commission's objective seems to be to 'outwit' arbitrators by closing down 'loopholes', eradicating discretion, and putting in place firm 'rules' on transparency of proceedings and impartiality of arbitrators. ${ }^{" 39}$ Proponents of ISDS have suggested that the proposed provisions in T-TIP may serve as a 'Gold standard' for the European Union's use of its new competences regarding FDI under the Common Commercial Policy. The scholars show this claim to be misleading at best, and expressed the hope that the current controversy over ISDS in T-TIP will prompt broad and serious debate about a sensible EU policy on existing and new investment Treaties in accordance with the values of Articles 2 and 3 of the Treaty on European Union that the Union is to promote in its relations with the wider world.

The Commission completed the public consultation ${ }^{40}$ and is preparing an imminent report on the use of ISDS in T-TIP, which will supposedly re-ignite the debate between the EU negotiators who favor pushing ahead with an arbitration clause in the future agreement, and the broad coalition of opponents. The whole report is expected to be published in December 2014 or January 2015, therefore the explosive debate is still not over.

\section{CONCLUDING REMARKS}

As the above analysis has shown, the negotiation on the T-TIP is based on strong economic arguments, namely, since both the EU and the US are facing decreasing world market shares and ability to compete with the emerging economies, the biggest motivation and perspective for the future agreement is the enhancement of the bilateral trade relations. Consequently, the T-TIP as free trade agreement will be form an exemption pursuant to GATT Article XXIV, in other terms, the agreement

Peter Muchlinski (SOAS School of Law), Horatia Muir Watt (Sciences Po Law School), Harm SchePEL (Kent Law School), and GuS VAN HARTEN (Osgoode Hall Law School).

37 Public consultation on investor-state arbitration in TTIP - Comment, available at: https://www.kent.ac.uk/law/downloads/ttip_isds_public_consultation_final.pdf [cit. 2014-12-19].

${ }^{38}$ See Online public consultation on investment protection and investor-to-state dispute settlement (ISDS) in the Transatlantic Trade and Investment Partnership Agreement (TTIP), European Commission, available at: http://trade.ec.europa.eu/consultations/index.cfm?consul_id=179 [cit. 2014-12-19].

39 Statement of Concern about Planned Provisions on Investment Protection and Investor-State Dispute Settlement (ISDS) in the Transatlantic Trade and Investment Partnership (TTIP), available at: https://www.kent.ac.uk/law/isds treaty_consultation.html [cit. 2014-12-19].

${ }^{40}$ The Commission, surprisingly, has received approx. 150.000 contributions. See Preliminary report (statistical overview) - Online public consultation on investment protection and investor-to-state dispute settlement (ISDS) in the Transatlantic Trade and Investment Partnership Agreement (TTIP), European Commission, available at: http://trade.ec.europa.eu/doclib/docs/2014/july/tradoc 152693.pdf [cit. 2014-12-19]. 
will apply 'legal discrimination' against the outside world. From this point of view, it seems to be not an exaggeration, that some analyses regard the T-TIP as a potential 'economic NATO.' 41

Therefore, the first concluding question is whether the T-TIP would mean really a threat for the third countries, specifically for the emerging markets. It is important that the customs duties towards the majority of the third countries, first of all, all WTO members, are low as the same way, as it is insignificant in the EU-US relation. The second component is the likely effects of standards and regulatory barriers, if the T-TIP will pay the way for harmonization and mutual recognition. However, if also the third countries will introduce and apply these standards, they will not face discriminatory effects.

The second question is how the T-TIP would affect the multilateral negotiations within the WTO. It is interesting not only from the perspective of the T-TIP, because both the EU and the US have recently opened and concluded negotiations on a number of bilateral trade agreements. Presumably, the bilateral trade negotiations and the 'revival of bilateralism', as the title of this paper suggests, is not itself the hindrance of the future multilateral talks within the WTO. It is rather a consequence of several changes which occurred in the international economic law and world trade in the last few decades. It means that the GATT-WTO system lifted effectively international trade barriers of various kinds in eight successful negotiation rounds, which covered predominantly the traditional trade measures, like customs tariff. Due to the successful liberalization agenda, the custom tariffs are fallen to a current historically low level. Though, it is relatively easy to lower the tariff barriers, which are generating low welfare gains, in comparison to the high level non-tariff barriers, which are very difficult to address among the 160 members of the WTO and find a mutually acceptable agreement on these issues. Probably, it is because the Doha Round is still not closed. However, it is expected the TTIP should not weaken neither the EU's nor the US' commitment to the WTO and a strong multilateral global agreement, and the T-TIP may indeed offer considerable template for future multilateral trade negotiations. ${ }^{42}$ As a consequence, the regulatory models and methods of the T-TIP would important not only for their impact on the EU and US alone, but also for the multilateral trade negotiations.

Thirdly, it is also obvious that the major benefits from T-TIP will come from the regulatory field and elimination of non-tariff barriers. Even if the chance of removal of regulatory trade barriers is every so often underestimated, mostly because of the strong 'self-confidence' of the EU and US legislators, it is worth noting, that even today converging tendencies are palpable in the relation of the US and EU legal order. The literature is analyzing the so called Brussels effect and demonstrates how the EU regulations are occupying e.g. the US environmental law. ${ }^{43}$ The EU seems to be a powerful actor in regulating the global markets, therefore it is likely that the negotiation on regulatory trade barriers will not hinder both parties to find a compromise.

Finally, as the two case-studies from the negotiation agenda - the environment and the investment have illustrated, some topics can raise significant public concern on both sides of the Atlantic. It is essential that the negotiating parties, especially the European Commission from the EU side, address

\footnotetext{
${ }^{41}$ It is not known who introduced this term first time, but even the policy papers of the Atlantic Council characterized the future agreement with using this language, see: GRAY, C. BOYDEN: An Economic NATO: A New Alliance for a New Global Order, Atlantic Council Issue Brief (February 2013) 1.

${ }^{42}$ Not mention here the potential for the future bilateral agreements in terms of BALDWIN's domino effect theory. See BALDWIN, RICHARD: A domino theory of regionalism, in: BHAGWATI, JAGDISH - KRISHNA, PRAVIN PANAGARIYA, ARVIND: Trading blocs: Alternative approaches to analyzing preferential trade agreements, 1999 , MIT Press, Cambridge, 479-502.

${ }^{43}$ For comprehensive analysis, see FAHEY, ELAINE: On the Use of Law in Transatlantic Relations: Legal Dialogues between the EU and US, in European Law Journal, Vol. 20. (2014) No. 3. 368-384. Bradford focuses on the Brussels effect as a more complex issue in a very suggestive way, see for instance, the sound introduction of the paper: "Few Americans are aware that EU regulations determine the makeup they apply in the morning, the cereal they eat for breakfast, the software they use on their computer, and the privacy settings they adjust on their Facebook page. And that's just before 8:30 AM." BRADFORD, ANU: The Brussels Effect, in Northwestern University Law Review, Vol. 107. (2012) No. 1. Recommendation for a Council Decision authorizing the opening of negotiations on a comprehensive trade and investment agreement, called the Transatlantic Trade and Investment Partnership, between the European Union and the United States of America. COM (12.3.2013) 136 3.
} 
the public interest and conduct a transparent dialogue on these issues. Public participation and more transparency could play an important role in facilitating these debated issues. It is the only way to lay the foundation of democratic legitimacy of the future agreement.

\section{LIST OF REFERENCES}

\section{Books, chapters in a book, articles}

[1] ABвOTT, FREDERICK M.: A new dominant trade species emerges: Is bilateralism a threat? in Journal of International Economic Law, Vol. 10. (2007) No. 3. 571-583.

[2] Araya, Monica - Figueres, Jose MARIA - SalaZAR-XirinaChS, Jose M.: Trade and Environment in the World Trade Organization: The Need for a Constructive Dialogue, in SAMPSON, GARY (ed.): The Role of the WTO in Global Governance, 2001, United Nations University Press, New York.

[3] BALDWIN, RICHARD: A domino theory of regionalism, in: BHAGWATI, JAGDISH - KRISHNA, PRAVIN PANAGARIYA, ARVIND: Trading blocs: Alternative approaches to analyzing preferential trade agreements, 1999, MIT Press, Cambridge, 479-502.

[4] BARUA, AKRUR - BANDYOPADHYAY, SUNANDAN: Revival in international trade and the resurgence of bilateralism, in Global Economic Outlook, (2014) No. 2. 60. Available at: http://dupress.com/articles/global-economic-outlook-q2-2014-revival-in-international-trade-and-theresurgence-of-bilateralism/ [cit. 2014-12-19].

[5] BRADFORD, ANU: The Brussels Effect, in Northwestern University Law Review, Vol. 107. (2012) No. 1.

[6] FAHEY, ElAINE: On the Use of Law in Transatlantic Relations: Legal Dialogues between the EU and US, in European Law Journal, Vol. 20. (2014) No. 3. 368-384.

[7] Felbermayr, Gabriel J. - Larch, Mario: The Transatlantic Trade and Investment Partnership (TTIP): Potentials, Problems and Perspectives, in CESifo Forum, Vol. 14 (2013) No. 2. 49-60.

[8] Froman, Michael: Remarks at the Transatlantic Trade and Investment Partnership First Round Opening Plenary (July 8, 2013), in Law and Business Review of the Americas, 2013, Vol. 19. (2013) $135-136$.

[9] Gray, C. Boyden: An Economic NATO: A New Alliance for a New Global Order, Atlantic Council Issue Brief (February 2013).

[10] ISADIKOV, AZIM: Border and Behind-the-Border Trade Barriers and Country Exports, IMF Working Paper (WP/07/292), December 2007.2 Available at: https://www.imf.org/external/pubs/ft/wp/2007/wp07292.pdf [cit. 2014-12-19].

[11] KESERŰ BARNA ARNOLD: A fenntartható fejlődés a GATT-WTO normarendszer tükrében [The sustainable development in the light of the GATT-WTO law], Diskurzus, 2013. 34-41.

[12] KeSERŰ BARNA ARNOLD: Review on the Role of Green Technologies in Hungarian Policies Concerning Sustainability, in KÁLMÁN JÁNOS (ed.): Legal Studies on the Contemporary Hungarian Legal System, 2014, Universitas-Györ Nonprofit Kft., Györ, 190-223.

[13]Lester, Simon - BARbeE. InU: The Challenge of Cooperation: Regulatory Trade Barriers in the Transatlantic Trade and Investment Partnership, Journal of International Economic Law, Vol. 16. (2013) No. 4.

[14]LeSTER, SIMON: Tackling Regulatory Trade Barriers in the Transatlantic Trade and Investment Partnership, in Cardoso, Daniel et. a. (eds.): Transatlantic Colossus - Global Contributions to Broaden the Debate on the EU-US Free Trade Agreement, 2013, Berlin Forum on Global Politics, Berlin.

[15]PARDAVI LÁSZLó: A globális gazdaság vámjogának alapkérdései (különös tekintettel a preferenciális szerzödésekre) [Main questions of the global economy's customs law (with specific regard to the preferential agreements)], Dissertation (manuscript), 2014, Széchenyi István University, Győr.

[16] SANTARIUS, TILMAN ET AL.: Balancing Trade and Environment: An Ecological Reform of the WTO as a Challenge in Sustainable Global Governance, 2004, Wuppertal Institute for Climate, Environment and Energy, Wuppertal,

[17] SCHOTT, JEFFREY J. - Cimino, CATHLEEN: Keys to negotiating the transatlantic trade and investment partnership, in Intereconomics, Vol. 48. (2013) No. 4. 263-264.

[18] VíG ZOLTÁN: Szabadkereskedelem és környezetvédelem: a WTO Vitarendezési Testületének gyakorlata [Free trade and environment: the case law of the WTO Dispute Settlement Body], in CSEHI ZOLTÁN Raffai Katalin (eds.): Állam és magánjog [State and private law], 2014, Pázmány Press, Budapest, 427-438.

[19] WróBeL, ANNA: Multilateralism or bilateralism: The EU trade policy in an age of the WTO crisis, Ekonomika, Vol. 92. (2013) No. 3. 


\section{Electronic sources}

[1] Barroso, José MANUEl DurÃo: Statement on the Transatlantic Trade and Investment Partnership. Joint press conference, Brussels (13 February 2013), available at: http://europa.eu/rapid/pressrelease_SPEECH-13-121_en.htm [cit. 2014-12-19].

[2] Centre for Economic Policy Research (CEPR) for European Commission - Reducing Transatlantic Barriers to Trade and Investment: An Economic Assessment (March 2013; hereinafter: CEPR assessment paper), available at http://trade.ec.europa.eu/doclib/docs/2013/march/tradoc_150737.pdf [cit. 2014-12-19].

[3] Final Report High Level Working Group on Jobs and Growth (February 11, 2013), available at: http://trade.ec.europa.eu/doclib/docs/2013/february/tradoc_150519.pdf [cit. 2014-12-19].

[4] Independent study outlines benefits of EU-US trade agreement, European Commission, MEMO/13/211 (12 March 2013), available at: http://europa.eu/rapid/press-release MEMO-13-211_en.htm [cit. 201412-19].

[5] Member States endorse EU-US trade and investment negotiations, DG Trade News Archive (14 June 2013), available at: http://trade.ec.europa.eu/doclib/press/index.cfm?id=918 [cit. 2014-12-19]

[6] Online public consultation on investment protection and investor-to-state dispute settlement (ISDS) in the Transatlantic Trade and Investment Partnership Agreement (TTIP), European Commission, available at: http://trade.ec.europa.eu/doclib/docs/2014/july/tradoc_152693.pdf [cit. 2014-12-19].

[7] Professor: Finland's legislative power may be in jeopardy, in Helsinki Times (15 Dec 2013), available at: $\quad$ http://www.helsinkitimes.fi/finland/finland-news/domestic/8717-professor-finland-s-legislativepower-may-be-in-jeopardy.html [cit. 2014-12-19].

[8] Statement of Concern about Planned Provisions on Investment Protection and Investor-State Dispute Settlement (ISDS) in the Transatlantic Trade and Investment Partnership (TTIP), available at: https://www.kent.ac.uk/law/isds treaty_consultation.html [cit. 2014-12-19].

[9] TTIP and the Arbitration Clause, in Euractiv Special Report (8-12 December 2014), 1. Available at: http://www.euractiv.com/files/euractiv_special_report_ttip_and the arbitration_clause.pdf [cit. 201412-19].

\section{Legal sources}

[1] 1219/2012/EU European Parliament and Council Regulation (12 $2^{\text {th }}$ December 2012) establishing transitional arrangements for bilateral investment agreements between Member States and third countries.

[2] C-350/12 P. Council versus in 't Veld, ECLI:EU:C:2014:2039.0

[3] Recommendation for a Council Decision authorizing the opening of negotiations on a comprehensive trade and investment agreement, called the Transatlantic Trade and Investment Partnership, between the European Union and the United States of America. COM (12.3.2013) 136

[4] Recommendation for a Council Decision authorizing the opening of negotiations on a comprehensive trade and investment agreement, called the Transatlantic Trade and Investment Partnership, between the European Union and the United States of America. COM(12.3.2013) 136 final.

[5] Commission Staff Working Document - Executive Summary of the Impact Assessment on the Future of the EU-US Trade Relations, SWD(12.3.2013) 69 final [cit. 2014-12-19]. 